\title{
Pain as a Conversion Symptom or a Psychosomatic Phenomenon: Fake or Real?
}

\author{
Kalliopi Chatira*
}

Faculty of Social Sciences, Department of Psychology. University of Crete, Greece

\begin{abstract}
According to the psychoanalytical Freudian approach, the pain in a conversion symptom (hysterical pain), whether defined or indefinable, corresponds to a displacement of the intrapsychic conflict to the subject's physical body. The libidinal energy attached to the repressed representation is transformed into neurotic energy in organs or parts of the body so as to dramatically represent the desirable as well as the prohibitive. The body lends itself as a 'location' to the conversion disorder in order for the anguish of the intrapsychic conflict to be expressed in openly manipulative terms. Does this hysterical pain designate both the pleasure of the performance and the discontent of the psychological anguish? On the contrary, the psychosomatic pain manifests itself in the actual physical body of the organism and not in the illusory body of the hysteric. It is possible for the (psycho)somatic disorder to be expressed through the pain symptom upon an existing, objective condition diagnosed in an organ or body part. But is it not the very nature of the psychosomatic disorder a unique differentiation criterion between the two types of the disorder? The rationale, the type of the psychological defense mechanisms and the nature of the impulsive dynamics which subdue each of those two types of painful symptoms constitute criteria of other differentiators within the psychopathological and psychoanalytic approach.
\end{abstract}

Keywords: Conversion symptom, pain, psychosomatic phenomenon.

\section{PAIN AS A CONVERSION SYMPTOM (HYSTERI- CAL PAIN)}

The conversion disorder refers to a psychological disorganization manifested, in the case of somatic symptoms, in severe conditions such as paralysis, anesthesia or various pains which appear in the absence of physical pathology. In addition, it intensifies various functional disorders such as severe abdominal pains, digestion disorders, headaches and migraines, severe backaches or pains in the extremities often accompanied by arm or leg paralysis etc. The list of painful symptoms is endless while these symptoms cannot be accounted for medically. The symptoms are nevertheless present, apparent and always invalidating the subject. Subjects typically act melodramatically and seductively, trying to inspire pity. This pattern is well identified and is called by Freud [1] conversion hysteria.

How does psychoanalysis account for such physical symptoms? Neurosis is a painful cause developed through conflicts between certain expressions and unconscious sexual desires as well as the expression of a prohibition aimed at the subject's these very desires; in other words, developed through conflicts between the 'id' and the 'superego'. The neurotic conflict is organized around the defense mechanisms of repression and representation and the unacceptable to the subject's 'superego' desires which are repressed in the unconscious. Actually, it is these very unconscious conflicts that end up in the organization of the hysteria. The mechanism of repression does not manage to fulfill its duty in the

*Address correspondence to this author at the Faculty of Social Sciences, Department of Psychology. University of Crete Greece;

Tel: +30 28310 77577; Fax: +302106990653;

E-mail: Chatirak@uoc.gr appeasement of the intense inner conflict, this resulting in the 'resurfacing' of the repressed material. Thus, the material which was supposed to remain repressed in the unconscious reappears modified as a neurotic symptom, i.e. a neurotic pain. Within hysteria (that is, the conversion phenomenon) the subject does not find the way to deal with conflicts stemming out of his/her impulsive ambivalence. In this morbid state, the conflict is being dramatized in the psychological sphere upon substantial representations, the well-known obsessions, and hysterical phobias. Therefore, the conflict is being displaced (externalized) to an object of the external reality; this fearsome object in turn leads the subject to an avoidance behavior. It is hereby that the pain declares the risk as a loud alarm that might mobilize or even handle the subject's environment, the internal (unconscious) as well as the external. The aim is a primary benefit for the unconscious and a secondary benefit gained in the form of pity in both an unconscious and a conscious level [2].

We need to define that these neurotic disorders point to the subject's psychosexuality and childhood, since these bodily misfortunes appear in order to express and interpret the unique modifications of the oedipal conflict within which the hysterical subject remains emotionally fixated. Based on this fact, the conversion disorder benefits the person in the sense of one's emotional libidinal 'economy'; on the other hand, it addresses unconsciously the problem of not being able to reconcile the two competing forces (the impulsive and the prohibitive). So, it is the subject's body that uptakes the effort to regulate this conflict via the symptom [3].

The conversion symptom in the form of a defined or indefinable pain (specified or not) corresponds after all to the relocation of the intrapsychic conflict upon the subject's li- 
bidinal and illusory body. A body part, often an erotic zone, is thus being chosen in order to impressively represent at the same time the desired and the forbidden. The pain defines simultaneously pleasure ('I suffer therefore I exist') and displeasure (I suffer, fondling my narcissistic ego and begging for the others' interest and attention). The libidinal energy attached to the repressed representation is being transformed to neurotic energy within body parts or organs. The body lends itself as a 'location', as a 'theatrical scene' to the conversion disorder in order for it to be expressed in openly manipulative terms. The suffering body part or organ appears particularly capable to assert itself. Regarding both psychic economy and uniqueness of the imaginative desire, the symptom is hatching in the defined location (the part of the body) serving as a theatrical scene where the repressed sexual conflict will be represented. Conversion, therefore, takes place in order to hurt or even paralyze a part of the body which could symbolically contribute in the realization of the subject's desire. In its purest form, the conversion disorder will prevent (via a prohibition paused by the 'superego') any fulfilling realization of this desire, while negotiating this realization indirectly and symbolically as a disguised expression of the 'id'.

The body is being used by the subject (particularly the subject's unconscious) in eloquent terms: the hysterical symptom of pain, as well as the other conversion symptoms, is there to interpret a psychological reality indescribable by words (since words would signify the recognition of thoughts and desires) and moreover in order to allow for the fantastic and illusory inspirations a free course. The body and its misfortunes permit the subject to symbolically depict the desired representation which had been suspended by an alert consciousness and/or 'superego'. Actually, if all this is being manifested upon a biological reality, then the conversion disorder primarily upraises a psychological rational. Its source lays within the sexual reality, that is, the psychosexual history of childhood and the person's emotional life. It appears that it is not so much the subject's 'actual body' within which the pain remains trapped as a feeling and as an awareness, but much more within the subject's 'erotic' or 'illusionary' body which seeks for 'relief' in the suffering of the conversion symptom. Freud [5] along with others like M. Sami-Ali [4] emphatically claims that the hysteric's body does not obey to the unique laws of anatomy and physiology; as a matter of fact, it obeys much more to the laws of an illusory anatomy and physiology which unconsciously refer to desire. It is still another manifestation of the extent in which the organism's emotional life has also departed from the rules of the primary psychological functions.

\section{PAIN AS A PSYCHOSOMATIC SYMPTOM}

The first differentiation criterion between the psychosomatic pain and the pain in the conversion phenomenon (hysteria) regards the nature of the disorder from a medical point. If the conversion symptom is being confused- as it often iswith substantial functional disorders, then we refer to a psychosomatic symptom. The psychosomatic pain manifests itself in the actual physical body of the organism and not in the illusory body of the hysteric. Here we are dealing with a disorder that could actually harm the body. The psychosomatic disorder will be 'located' upon an existing, objective and diagnosed medical condition of an organ or body part, more likely a tissue; it will be possibly accompanied by the symptom of pain. This trauma constantly disturbs the normal function of the organism in both the physical and the psychological level. The actual and objective reality of the physical condition often adds to the severity of the identified psychosomatic disorder. On the contrary, the pain in the previously mentioned and fully reversible conversion disorder never threatens the life of the suffering subject.

Unlike the conversion symptom, the psychosomatic symptom does not refer to the person's childhood but to current negative life events and misfortunes. It is this psychosomatic symptom which gets (and already is) registered in the person's subjective history [6]. The psychosomatic symptom does not return to the psychosexuality; it interprets the positions of the body's unsuccessful erotogenetic mechanisms [7]. According to P. Marty's [8] open view point, somatization corresponds to a person's gradual psychological disorganization, since the person is unable to find his/her way to his/her own mental and physical stabilization threshold, a point that would instantly reduce psychic tension and allow for reorganization. The psychosomatic pain symptom is the result of a subject's weakness or inability (more coincidental than structural) to (psycho) intellectually process his/her conflicts and impulsive excitations. Pain in the psychosomatic patient is a complaint, an expression of tension and absorption of psychological tension and intra-psychic throbs. In other words, the psychosomatic symptom appears because the person fails to bind up his/her excitations or represent traumatic situations in his/her thinking apparatus: the person fails to rationalize, to sublimate, and to idealize [9]. Actually, the patient fails to regard as subjective the facts or the events of his/her history, particularly his/her present history. The psychosomatic symptom is not alleged or underlined by repression or displacement as in hysteria [10]. It is more a drawback of suspension mechanisms and more widely an absence of intellectualization which characterizes the psychic economy of the psychosomatic patient.

According to L. McDougall $[11,12]$, psychosomatic patients are unable to feel or express an emotion and particularly unable to overcome an emotional experience. It is through somatization that such patients become able to express and tolerate the nature of painful representations and emotions as well as the type of their conflicts.

\section{THE PAIN: FAKE OR REAL?}

How does one reach such clinical differentiation? Is the pain fake or real? How much does the hysteric and how much does the psychosomatic patient suffer? We now need to consider the origins of this certified differentiation between the conversion disorder and the psychosomatic symptom. The psychosomatic symptom is identified in Freud's $[10,13]$ work on the present neurosis. Soon, Freud [1, 5] picks out a clearly distinct category of somatic disorders within the somatic hysterical symptoms, the so called 'present neuroses'. First he includes neurasthenia and anxiety neurosis and then hypochondria in this category, thus managing to suggest some symptomatic clusters different than the psychoneuroses. This is how the psychosomatic disorder appears $[14,15]$. These new clusters are characterised, among other things, by a distinct number of somatic symp- 
toms such as fatigue, chronic defined or indefinable pains, headaches and migraines, abdominal pains but especially anxiety attacks combined with actual recurring functional conditions such as heart, respiratory or gastrointestinal problems. But as clearly stated by Freud [1,5], these physical symptoms do not follow the mechanisms of the somatic conversion symptoms. He certainly mentions that both the present neurosis and the hysterical conversion are characteristic of the patient's sexual life. In the former, though, the physical disorders are apparent in the person's existing and current sexual behaviour and stem out of his/her incoherent genetic life while in the latter the physical disorders point back to childhood psychosexuality and especially to the oedipal complex. Therefore, causation better differentiates the two conditions and the resulting pain symptoms: the psychosomatic pain is a physical expression of the present neurosis while the hysterical pain in the conversion phenomenon is of a psychic- structural nature. There is nothing alike between the conversion symptom and the physical disorders combining the present neurosis in the psychosomatic symptom. The psychosomatic pain does not correspond to a neurotic unconscious conflict and therefore it is not structural (regarding the person's dynamic structure). Thus, it does not bare any symbolic meaning nor does it express an incomplete or maladjusted relief of sexual arousal. The psychosomatic pain appears to be the legacy of a physical disorder manifested in the present neurosis since it is described as a symptom deviating from the laws, rules and repression mechanisms of the hysteric conversion; on the contrary, it states an alleviation of psychic tension.

Therefore, we are faced with the obvious question of the validity of the clinical differentiation of pain as a conversion symptom or a psychosomatic phenomenon. In the former, the pain symptom finds a location in the body, more precisely in the illusory body, in order to re-enact the anguish of an impulsive conflict and a 'hurt' narcissism. In the latter, the psychosomatic phenomenon of pain expresses in a nonrandomly selected part of the actual body the person's inability to manage the anxiety and tension caused by active and present painful life circumstances. In the conversion symptom, the body lends the mind (the psyche) its parts as a theatrical scene for the performance of a painful pretence. In the psychosomatic phenomenon, the body borrows by the mind in order to express and relieve the psychological tensions caused by negative life events, frustrations and losses.

The mind and the body function as a whole and in such a relationship the pain as a perception and an emotion affects the organism's entire system (soma and psyche) [16]. The pain, either physical and caused by an injury or lesion or psychological and caused by a psychological trauma, structural or present, it always expresses emotional discomfort and anguish. Whether fake and expressed in the illusory body as a conversion symptom, or real and occurring in the actual body as a psychosomatic phenomenon expressing complain, protest or a need to attract attention, it bares the same value since the person is in a 'suffering' state seeking for a relief of intrapsychic tension. We can, therefore, state that there is not real or unreal pain in the psychoanalytic approach. There is only pain of different 'texture', as the flip sides of the same coin, the value of which can only be estimated in the person's suffering and in his/her relief in the field of clinical practice.

\section{CONFLICT OF INTEREST}

The author confirms that this article content has no conflict of interest.

\section{ACKNOWLEDGEMENTS}

Declared none.

\section{PATIENT'S CONSENT}

Declared none.

\section{REFERENCES}

[1] Freud S. Fragment d'une analyse d'hystérie (Dora), Cinq psychanalyses. Paris: PUF; 1981, pp. 1-91.

[2] Jeanneau A. L'hystérie. Unité et diversité, Revue française de psychanalyse. 49(I), no spécial, 1985; pp. 107-326.

[3] Marty P., De M'Uzan M. La pensée opératoire, Revue française de psychanalyse. 27, no spécial, 1963; pp. 345-56.

[4] Sami-Ali M. Penser le somatique. Imaginaire et pathologie, Paris, Dunod; 1987.

[5] Dumet N. Clinique des Troubles Psychosomatique: Approche Psychanalytique. Paris: Dumont; 2001.

[6] Del Volgo M.J. L'Instant de dire. Le mythe individuel du malade dans le médecine moderne. Ramonville-Sainte-Agne, Érès; 1997.

[7] Lefebvre P. La psyché de la somatose en quête de névrose. Le sentier obstrué. Revue française de psychanalyse. 48, 5, 1984; pp. 1173-82.

[8] Marty P. L'Ordre psychosomatique, t, I: Désorganisations et régressions. Paris, Payot; 1980.

[9] Chatira K. Les Troubles psychosomatique: Approche psychanalytique. Notes universitaires. Faculté de sciences sociales, Département de la Psychologie, Université de Crète; 2012.

[10] Freud S. Mademoiselle Elisabeth von R., in S. Freud et J. Breuer, Études sur l'hystérie. Paris: PUF, 1990; pp. 106-45.

[11] McDougall J. Corps et langage. Du langage du soma aux paroles de l'esprit. Revue française de psychosomatique, 2, 1992; pp. 69-96.

[12] McDougall J. Théâtres du corps. Le psychosoma et psychanalyse, Paris: Gallimard; 1989.

[13] Freud S. Du bien-fondé à séparer de la neurasthénie un complexe de symptôme déterminé en tant que névrose d'angoisse, Euvres complètes, Psychanalyse. III, Paris: PUF, 1989; pp. 29-58.

[14] Freud S. L'inquiétante étrangeté, L'Inquiétante étrangeté et autres essais, Paris: Payot, 1985; pp. 211-63.

[15] Freud S. Au-delà du principe du plaisir, Essais de psychanalyse. Paris: Payot, 1981; pp. 41-115.

[16] Freud S. Manuscrit E. De l'origine de l'angoisse », in La Naissance de La psychanalyse. Paris: PUF, 1985; pp. 80-5. 